\title{
Reparative Regeneration by Substitution of Bone Tissue Defects with Bioglass, Using Regeneration Technologies
}

\author{
Regeneración Reparadora Mediante Sustitución de Defectos del \\ Tejido Óseo por Biovidrio, Utilizando Tecnologías de Regeneración
}

Olexander A. Buryanov ${ }^{1}$; Volodymyr S. Chornyi ${ }^{1}$; Vitaly A. Dubok ${ }^{2}$; Serhii I. Savosko'; Miroslav V. Vakulych ${ }^{1}$; VolodymyrV. Protsenko ${ }^{3}$; Taras M. Omelchenko ${ }^{1}$; Olexandr V. Shynkaruk ${ }^{2}$ \& Andrii P. Kusiak ${ }^{4}$

BURYANOV, O. A.; CHORNYI, VOLODYMYR, S. C.; DUBOK, VITALY, A.; SAVOSKO, S. I.; VAKULYCH, M. V.; PROTSENKO, V. V.; OMELCHENKO, T. M.; SHYNKARUK, O. V. \& KUSIAK, A. P. Reparative regeneration by substitution of bone tissue defects with bioglass, using regeneration technologies. Int. J. Morphol., 39(1):186-191, 2021.

SUMMARY: Bioactive glass (BG) induces osteogenesis of damaged bone, causing excessive bone formation. This study included a morphological and morphometrical data of the bone tissue regeneration by filling bone defects with BG with autologous native platelet rich plasma (PRP) or fibrin (PRF) and aspirate of bone marrow (ABM). The parameters of newly formed bone in rabbits bone defect were analyzed and compared with terms 4th and 12th week. The groups with ABM-BG, PRF-BG and PRP-BG have shown common tendency: development of newly formed bone tissue, the external contour of the bone has been enlarged; an additional trabecular bone has been formed under the cortical layer, which has often been limited by a solid compact bone from the bone marrow. The induced osteogenesis resulted in the appearance of a significant amount of bone tissue exceeding the original size of the defect. Increased density of the newly formed tissue at the defect level relative to ABM-BG was detected in the PRF-BG group at 12 weeks and PRP-BG at 4 and 12 weeks $(\mathrm{p}<0.05)$. In this case, the bone thickness in the substituted defect was greater in the ABM-BG group. The number of newly formed bone tissue in the ABM-BG group at 4 weeks also exceeded the value of the BG group, but the density of such bone did not differ between the groups. That is, ABM-BG stimulated greater trabecular bone formation and fibrous reticular tissue was located in the lacunae between trabeculae. These results indicate that the additional use of tissue technology (ABM, platelet plasma) facilitated osteogenesis, and the newly formed bone tissue was tightly coupled and remodeled to the cortical bone layer in the form of compact bone tissue. PRP, to a greater extent than $\mathrm{ABM}$, promoted the formation of compact bone tissue.

KEY WORDS: Bone regeneration; Bioactive glass; Platelet-rich fibrin; Aspirate of bone marrow; Platelet rich plasma fibrin.

\section{INTRODUCTION}

The choice of biomaterials is predisposed for their bioactive properties i.e., they don't cause negative immune response, being able to integrate with the bone by the direct biochemical bonds. Nevertheless, their biochemical properties differ. Bioactive glass $(\mathrm{BG})$, as a synthetic biomaterial, is characterized by biomechanical and morphological steadiness as well as high elasticity, being similar to hydroxyapatite (HA) and $B$-tricalciumphosphate(ß-TCP).

The use of ceramic biomaterials in replacing bone defects is one of the promising areas of reconstructive surgery. The choice of biomaterials is based on the fact that they do not cause adverse reactions and are able to integrate with bone due to the formation of direct biochemical bonds, have mechanical stability, high elasticity (Polo-Corrales et al., 2014).

The synthetic HA is by its chemical composition and crystal structure most similar to the bone tissue mineral substance, with its expressed osteoconductive properties (bone tissue proliferation into the HA implant surface), though the HA resorption and biotransformation speed are usually the lowest among the chosen materials, so, as a result of osteoconduction, there forms a densely integrated bone tissue-HA mix, the so-called bone-ceramic complex, which

\footnotetext{
1 Department of Traumatology \& Orthopedics, Departmentof Histology \& Embryology, Bogomolets National Medical University, Ukraine.

2 Department $N^{\circ}$ 58,Structural chemistry of solids, Frantsevich Institute of Problems of Materials Science NASU, Ukraine.

3 Department for Foot Pathology and Complex Prosthetic Treatment,SI "The Institute of Traumatology and Orthopedics"by NAMSU, Ukraine.

4 Department of Nanomaterials, Cehuiko Institute of Surface Chemistry of NASU, Ukraine.
} 
BURYANOV, O. A.; CHORNYI, VOLODYMYR, S. C.; DUBOK, VITALY, A.; SAVOSKO, S. I.; VAKULYCH, M. V.; PROTSENKO, V. V.; OMELCHENKO, T. M.; SHYNKARUK, O. V. \& KUSIAK, A. P. Reparative regeneration by substitution of bone tissue defects with bioglass, using regeneration technologies. Int. J. Morphol., 39(1):186-191, 2021.

may stay in the body for years (Gomes et al., 2019). B-TCP possesses biochemical properties, similar to HA, but with quicker resorption, which results in local implant reconstruction and its participation in the bone tissue restoration rather than the bone-ceramic complex formation (Yu et al., 2017).

The BG is a material with the highest bioactivity index, it quickly integrates into the bone tissue due to formation of the apatite layer on its surface, which is totally similar to the adjacent bone (Fiume et al., 2018). The BG osteointegration and biotransformation processes are accelerated by release of the bioglass $\mathrm{Si}$ and $\mathrm{Ca}$ ions, which stimulate bone regeneration (Fernandes et al., 2018). Though, all the recalled effects of the synthetic bioactive materials implantation presumably depend on the conditions and place of implantation as well as the patient's physical condition.

Revascularization and remodeling of the bone tissue represent a separate issue. A possible method of providing for these two processes is combination of biomaterials, which, as a frame, possess certain mechanical properties for mechanical support, with the growth factors, which induce the bone tissue formation (Rodriguez et al., 2014). Both PRP and PRF serve a potential source of these factors, and reaction with the thrombin and calcium ions leads to considerable release of the previously accumulated growth factors into the local issues. The plasma, enriched with thrombocytes, stimulates osteogenesis, as the thrombocytes, being destroyed in the bone defect, produce various angiogenic, mitogenic and osteogenic growth factors, which, in their turn, trigger and activate the osteogenesis processes (Meschi et al., 2016). On the other side, combination of the thrombocyte gel with the fibrin glue, bone marrow aspirate or simvastatin haven't detected significant differences in bone healing compared to the control group (Rodriguez et al.). Bassi \& de Carvalho (2011) found that PRP associated with bovine inorganic bone (Bio-Oss ${ }^{\circledR}$; Geistlich) or BG (Bio-Gran ${ }^{\circledR}$; Orthovita, Implant Innovations) did not have a significant effect on bone healing in dogs.

In Ukraine, such studies have not been performed yet. In other countries there are several experimental studies of BG in combination with cell therapy in vivo. The use of $\mathrm{BG}$ is one of the most effective materials for implantation. But insufficiently studied in the literature is the possibility to improve the results of BG implantation in bone defects, with the simultaneous use of different cell technologies. A limited number of studies on the use of PRP in combination with BG in patients have not shown statistically significant differences between the two treatments for the healing of intraosseous defects of the jaws (Demir et al., 2007).
The study of this issue optimizes the use of calcium phosphate materials and cell therapy in clinical practice to fill bone defects. The aim of the present study was to study the bone tissue regeneration with bone defects filled with the BG with ABM, PRP and PRF.

\section{MATERIAL AND METHOD}

Experimental model. Thirty four rabbits, weighing 3530 $\pm 72 \mathrm{~g}$, were used in the study. A bone defect, $2 \mathrm{~mm}$ in diameter, was produced in the proximal metaphysis of the tibia under general ketamine anesthesia. The defect was further filled with the cylinder blocks with BG, soaked in the autologous plasma represented by the platelet rich plasma (PRP), platelet rich fibrin (PRF) or aspirate of bone marrow (ABM).

BG is represented with the synthetic biomaterials produced by company "Syntekist" (I-Plant Ltd., Ukraine), which have been permitted to be used clinically in Ukraine. The $\mathrm{BG}$ composition is as follows: $58 \% \mathrm{SiO}_{2}-33 \% \mathrm{CaO}$ $-9 \% \mathrm{P}_{2} \mathrm{O}_{5}$, synthesized by the sol-gel method, burnt at the final synthesis stage under $850{ }^{\circ} \mathrm{C}$, its specific surface is about $130 \mathrm{~m}^{2} / \mathrm{g}$. The BG was shaped in blocks, $2 \mathrm{~mm}$ in diameter and $4 \mathrm{~mm}$ in length. The authors used implantation method described in ISO 10993-6:2015 (Biological evaluation of medical facilities. Part 6.Trials of local effects after implantation).

PRP was received after a single animal blood centrifugation with citrate during 10 minutes under the speed of $1200 \mathrm{rot} / \mathrm{min}$, under room temperature. ABM was received by paracentesis of the femur bone canal, with its single centrifuging with sodium citrate during 10 minutes under the speed of 400rot $/ \mathrm{min}$, under room temperature.

The study includes two stages of trials, with 10 animals in each.

Histological studies. On the $4^{\text {th }}$ and $12^{\text {th }}$ weeks, the animals were removed from the study by injecting $1.0 \mathrm{ml}$ of $10 \%$ thiopental solution into the ear vein. The tibia was fixed in $10 \%$ solution of neutral formaldehyde ( $\mathrm{pH}$ 7.4). After fixation and cleaning the samples were stored in the decalcifying solution OsteoFast 2 (BioGnost Ltd., Croatia).Transverse fragments $2-3 \mathrm{~mm}$ in width were excised from the bone on the defect level, to be further dehydrated in ascending ethanol concentrations (70 \%-96 $\%)$ and absolute isopropyl alcohol; and then placed into paraffin ( 3 trays of paraffin, $56^{\circ} \mathrm{C}$ ) (Leica Surgipath Paraplast Regular) (Bourque et al., 1993). The paraffin 
BURYANOV, O. A.; CHORNYI, VOLODYMYR, S. C.; DUBOK, VITALY, A.; SAVOSKO, S. I.; VAKULYCH, M. V.; PROTSENKO, V. V.; OMELCHENKO, T. M.; SHYNKARUK, O. V. \& KUSIAK, A. P. Reparative regeneration by substitution of bone tissue defects with bioglass, using regeneration technologies. Int. J. Morphol., 39(1):186-191, 2021.

organ sections $10 \mu \mathrm{m}$ in width were made using the microtome ThermoMicrom HM 360. The sections were deparaffinated, rehydrated and stained with hematoxylin and eosin (H\&E) (Cardiff et al., 2014).

Morphometric studies of the bone tissue within the tibia width in the defect area were made, which were then compared to the contralateral bone. Microphotos of the defected bone $\mathrm{H} \&$ E-stained histological sections (magn $\times$ 40) were made by microscope Olympus BX 51. The bone tissue in these areas was measured (which included from 3 to 14 measurements in each region) using the software Carl Zeiss (AxioVision SE64 Rel.4.9.1), to calculate the bone tissue relative amount $(\%)$ of the measured defect total area. For technical solution of the task publications with similar methods of the bone density assessment were analyzed (Rolvien et al., 2017; Scimeca et al., 2017).

Statistical analysis. The data was expressed as a median $(\mathrm{Me})$, its lower $(25 \%)$ and upper $(75 \%)$ quartiles $\left(\mathrm{Q}_{25}-\mathrm{Q}_{75}\right)$. The data were statistically processed using the software Origin Lab, version 8.0. (OriginLab Corporation, USA). Kruskal-Wallis H-criterion was used to check for the statistically significant difference. The difference was considered statistically reliable with $\mathrm{P}<0.05$.

Bioethics. All animals were under the supervision of a veterinarian in standard conditions of an accredited vivarium of the Bogomolets National Medical University. The research was conducted in compliance with the general principles of bioethics, in accordance with the "European Convention for the Protection of Vertebrate Animals used for Experimental and other Scientific Purposes" (Strasbourg, 1986) and the Law of Ukraine N ${ }^{\circ}$ 3447-IV of 21.02.2006 "On the Protection of Animals from Cruelty" in the natural light-dark cycles and had free access to water. The test report was approved by theBioethics Commission of SI "ITO NAMNU" (protocol $\mathrm{N}^{\circ} 1$, issued in 2020). Surgery was performed under general ketamine anesthesia and every effort was made to minimize suffering.

\section{RESULTS}

The $4^{\text {th }}$ and $12^{\text {th }}$ week group with ABM-BG, PRF$\mathrm{BG}$ and PRP-BG showed bone reparative regeneration in the defect region. Common tendency was noted, which was development of the bone tissue around the BG. The BG was surrounded with bone trabeculae, including osteoblasts and single osteoclasts. The BG was a focus of the induced osteogenesis in cortical and spongy bones (Fig. 1).

So, the newly formed bone, which substituted the cortical bone defect, is represented with the membrane reticulated bone, and it forms lacunae, in which fiber-reticular tissues are registered. It is rare that the tissue with the bone marrow reparation traces may be observed here. The bone tissue showed osteocytes in lacunae as well as the acellular regions and single osteoclasts. Quite often the external and internal contours of the newly formed cortical bone by its histology resembled healthy bone.

The study established difference in osteogenesis degree according to the terms and groups to be compared. A result of the induced osteogenesis was appearance of significant amount of the bone tissue, which exceeded the initial defect size, particularly in group ABM-BG (Table I). The statistically significant increase of the newly formed tissue density on the defect level related to ABM-BG was revealed in PRF-BG group on the 12th week, and to PRPBG on the $12^{\text {th }}$ week $(p<0.05)$.

Here the bone width in the substituted region was higher in group ABM-BG. The amount of the newly formed bone tissue in group ABM-BG on the 4th week of the study also was higher than in BG group, but the bone density didn't differ between the groups. The last one fills the lacunae between the bone trabeculae. Increased width of the newly formed bone around the biomaterial localization evidences about material biocompatibility with biological tissues.

Table I. Morphometry of the tibia defect region, $\mathrm{Me}\left[\mathrm{Q}_{25}-\mathrm{Q}_{75}\right]$.

\begin{tabular}{llcc}
\hline & Group & $\begin{array}{c}\text { Width of the bone wall in the } \\
\text { defect region, } \mu \mathrm{m}\end{array}$ & $\begin{array}{c}\text { Density of the bone tissue } \\
\text { in the defect region, } \%\end{array}$ \\
\hline 1 & ABM-BG -4 weeks & $3691.3[2983.5-3877.0]$ & $61.8[54.7-77.0$ \\
2 & ABM-BG -12 weeks & $3095.0[2716.6-3356.3]$ & $64[50.5-66.2]$ \\
3 & PRF-BG -4 weeks & $1922.6[1797.6-3804.6]$ & $76.8[54.5-81.9]$ \\
4 & PRF-BG -12 weeks & $1942.2[1669.2-2756.9]^{*}$ & $75.1[63.2-80.3]^{*}$ \\
5 & PRP-BG -4 weeks & $1851.5[1763.6-1899.5]^{*}$ & $83.2[68.5-88.1]^{*}$ \\
6 & PRP-BG -12 weeks & $2544.2[1410.7-3564.6]$ & $70[66.5-75.8]^{*}$ \\
\hline BG - bioglass; ABM - aspirate of bone marrow; PRP - platelet rich plasma; PRF -platelet rich fibrin; * - p<0.05 \\
compared to group ABM-BG.
\end{tabular}



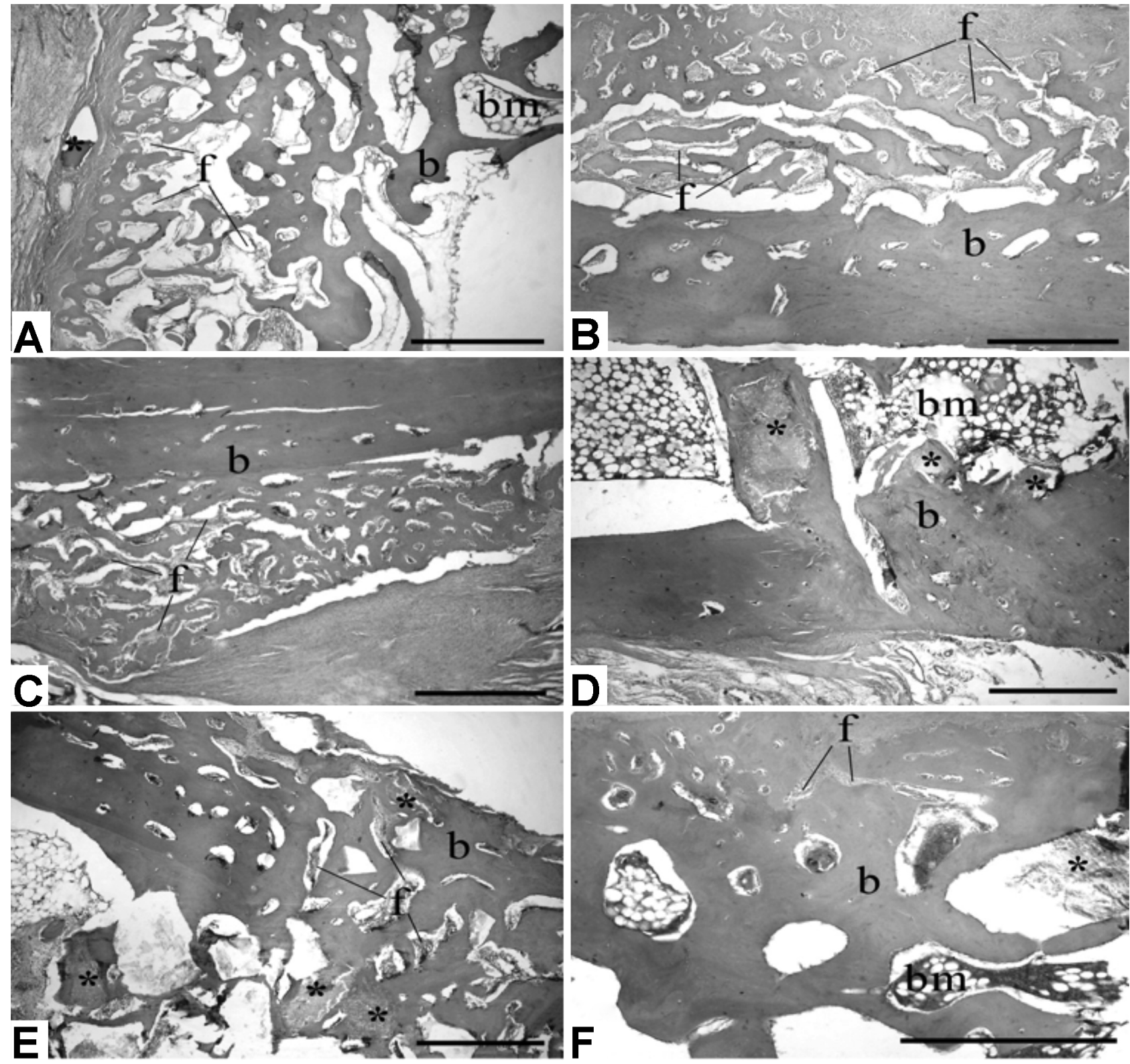

Fig. 1. Bone regeneration in the defect, bioglass particles surrounded by newly formed bone tissue. A and B - ABM-BG on 4 and 12 week; C and D - PRF-BG on 4 and 12 week; E and F - PRP-BG on 4 and 12 week; * - bioglass particles; b - bone tissue; bm - bone marrow; $\mathrm{f}$ - fibroreticular tissue. Hematoxyline and eosin stain, scale bar $=500 \mu \mathrm{m}$.

\section{DISCUSSION}

In this report, we investigated the introduction of autologous ABM, PRP and PRF can improve the osteogenic potential of bone tissue when filling bone defects with BG. Calculation of histomorphometric data is the key method in comparing the results of the effectiveness of combinations of materials in the replacement of bone defects (Rolvien et al.; Scimeca et al.). A study similar to ours, which evaluated effectiveness of the PR and BG (groups: BG, BG+PRP, control defect group), didn't show statistically significant difference in the newly formed tissue area in 4 weeks after the intervention, though, in 12 weeks after the best results were observed in group BG+PRP. (Zhang et al., 2011). We established statistically significant difference on the $12^{\text {th }}$ week between groups PRP-BG and PRF-BG to comparative 
BURYANOV, O. A.; CHORNYI, VOLODYMYR, S. C.; DUBOK, VITALY, A.; SAVOSKO, S. I.; VAKULYCH, M. V.; PROTSENKO, V. V.; OMELCHENKO, T. M.; SHYNKARUK, O. V. \& KUSIAK, A. P. Reparative regeneration by substitution of bone tissue defects with bioglass, using regeneration technologies. Int. J. Morphol., 39(1):186-191, 2021.

group ABM-BG (difference within 6-11\%; $\mathrm{p}<0.05$ ). Our results did not show any statistical difference in density of regenerated bone tissue between PRP-BG and PRF-BG groups on the $12^{\text {th }}$ week. However, on the $4^{\text {th }}$ week the tendency for repair processes around PRP-BG sites was observed $(\mathrm{p}<0.05)$. The study also established the absence of statistically significant difference on the $4^{\text {th }}$ week in group PRF-BG by both bone tissue density and tibia defect wall width. Group ABM-BG was characterized with significant difference by the bone tissue wall width $(\mathrm{p}<0.05)$.

The study, similar to ours, mentioned previously, used analysis of PRF+ B-TCP combination application, compared to single ß-TCP use (Yilmaz et al., 2014). According to the histomorphological studies (criterion area of the bone tissue in $\mu \mathrm{m}^{2}$ ), the authors established statistically significant difference between the control and compared groups (in 12 weeks) after intervention. Slightly better parameter in 12 weeks was observed in group with combined application (average area in group PRF+ $\beta-\mathrm{TCP}$ $=22,1 \mathrm{~mm}^{2}$, in group $\left.B-\mathrm{TCP}=21,1 \mathrm{~mm}^{2},=0.043\right)$. Comparison of $\mathrm{PRP}+\beta-\mathrm{TCP}$ and bone marrow aspirate $+\beta$ TCP, showed that the higher bone tissue density (higher share of the bone tissue in the studied area) was defined in groups where $\mathrm{PRP}+\beta-\mathrm{TCP}$ was used (Bi et al., 2010; Batista et al., 2011; Yu et al.).

Other similar studies and bone tissue defect treatment included: control defect; autobone (spongy bone) HA; HA + PRP; HA + mesenchymal stem cells; HA + mesenchymal stem cells + PRP. The best biochemical data (Jung module) was established in 4 weeks in groups with autobone- and combination HA+PRP $(\mathrm{p}<0.05)$. Histomorphological data were the newly formed bone tissue area, with best results in groups HA + mesenchymal stem cells and HA + mesenchymal stem cells + PRP $(p<0.05)$. The group HA + PRP didn't show statistically significant difference with the control group (Kasten et al., 2008; Oryan et al., 2012). Our study didn't find statistically significant difference with the compared group on the $4^{\text {th }}$ week.

In trials on rabbits the osteogenesis stimulation of substituted bone segment was compared: that one with PRP and without it. The study revealed quicker healing of the bone tissue due to combined materials use (Zhang et al.).

The authors used BG obtained by sol-technology, for regeneration of premolar defects in dogs, with and without PRP. Increased width of the bone and histological development of bone tissue were observed, compared to the control group without biomaterial applied. Groups BG and PRP showed higher area of the bone tissue and more mature bone tissue than the BG without PRP. These results show that the sol-gel BG with PRP may improve reparative regeneration and width of the bone tissue (Rodriguez et al.).

Another study used both borateBG with PRP for regeneration of the bone tissue in rabbit diaphysis. Twelve weeks after implantation the histological studies and microCTscan showed that in the group with PRP, there was increased development of bone tissue (Zhang et al.). BG combined with PRO turned to be effective for eliminating defects of bones, thus requiring further studies.

Bassi \& de Carvalho reports that PRP associated with bovine inorganic bone (Bio-Oss ${ }^{\circledR}$; Geistlich) or BG (BioGran®; Orthovita, Implant Innovations) did not have a significant effect on bone healing in dogs. Also it was reported irrelevant improvement of bone repair by using HA + PRP compare to HA (Oryan et al.).

In Yu et al. study, bone segmental defects of critical size $(12 \mathrm{~mm})$ in rabbits were replaced using cylindrical blocks with $B$-TCP with or without PRP. After 4 and 8 weeks, radiographic and histological observations showed that the group with PRP gave $13.3 \%$ and $10.28 \%$ higher volume of regenerated bone than the group without PRP.

The introduction of PRP into the $\beta-\mathrm{TCP} /$ chitosan composite significantly improved biocompatibility and osteoinduction without compromising the mechanical strength of the new bone in a goat. From 4 to 16 weeks after implantation, tibial defects fully recovered, with more mature bone formation and less composite residue by $15-40 \%$ than without PRP (Bi et al.).

Thus, the replacement of bone defects with a material based on BG is an effective analogue of HA, B-TCP, and the results of implantation can be improved through the simultaneous use of cell technology.

Limitations. The use of PRP is limited to have well-known contraindications: Thrombocytopenia, hypofibrinogenemia, collapse, infections, chronic liver disease, anticoagulation therapy, cancer. BG, like other calcium phosphate implant materials, does not cause side effects within the instructions for use. In our further research we will study the ceramic calcium phosphate materials and bioglass and their combination with cell therapy to replace massive bone defects in orthopedics.

\section{CONCLUSIONS}

1. Bioglass significantly induces osteogenesis of the affected bone and leads to over-production of the bone tissue, which can be used in the treatment of its defects. 
2.Additional use of tissue technologies (bone marrow aspirate, platelet enriched plasma) with bioglass promoted osteogenesis, and the newly formed bone tissue is tightly combined and remodeled with cortical layer of the bone as compact bone tissue, which is confirmed by data from other experimental studies, but requires further clinical.

3. PRP and PRF more than provided for compact bone tissue formation in 12 weeks after regeneration and can be used to develop cell therapy.

BURYANOV, O. A.; CHORNYI, VOLODYMYR, S. C.; DUBOK, VITALY, A.; SAVOSKO, S. I.; VAKULYCH, M. V.; PROTSENKO, V. V.; OMELCHENKO, T. M.; SHYNKARUK, O. V. \& KUSIAK, A. P. Regeneración reparadora mediante sustitución de defectos del tejido óseo por biovidrio, utilizando tecnologías de regeneración. Int. J. Morphol., 39(1):186-191, 2021.

RESUMEN: El vidrio bioactivo (VB) induce la osteogénesis del hueso dañado, provocando una formación excesiva de hueso. Este estudio incluyó datos morfológicos y morfométricos de la regeneración del tejido óseo mediante el llenado de defectos óseos con VB con plasma rico en plaquetas (PRP) nativo autólogo o fibrina (PRF) y aspirado de médula ósea (AMO). Se analizaron los parámetros de hueso recién formado en el defecto óseo de conejos y se compararon a las 4 y 12 semanas. Se observó una tendencia similar en los grupos con AMO-VB, PRF-VB y PRP-VB: el desarrollo de tejido óseo recién formado, aumentó el contorno externo del hueso; formación de un hueso trabecular adicional debajo de la capa cortical, que a menudo ha estado limitada por un hueso sólido compacto de la médula ósea. La osteogénesis inducida dio como resultado la aparición de una cantidad significativa de tejido óseo que excedía el tamaño original del defecto. Se detectó un aumento de la densidad del tejido recién formado a nivel del defecto en relación con $\mathrm{AMO}-\mathrm{VB}$ en el grupo PRF-VB a las 12 semanas y PRP-VB a las 4 y 12 semanas ( $p<0,05$ ). En este caso, el grosor óseo en el defecto sustituido fue mayor en el grupo AMO-VB. El número de tejido óseo recién formado en el grupo AMOVB a las 4 semanas también excedió el valor del grupo VB, pero la densidad de dicho hueso no cambió entre los grupos. Es decir, AMO-VB estimuló una mayor formación de hueso trabecular y se localizó en el tejido reticular fibroso en las lagunas entre trabéculas. Estos resultados indican que el uso adicional de tecnología de tejidos (AMO, plasma plaquetario) facilitó la osteogénesis, y el tejido óseo recién formado se acopló y remodeló estrechamente a la capa de hueso cortical en forma de tejido óseo compacto. El PRP, en mayor medida que el AMO, promovió la formación de tejido óseo compacto.

PALABRAS CLAVE: Regeneración ósea; Vidrio bioactivo; Plasma rico en plaquetas; Aspirado de médula ósea; Fibrina plasmática rica en plaquetas.

\section{REFERENCES}

Bassi, A. P. F. \& de Carvalho, P. S. P. Repair of bone cavities in dog's mandible filled with inorganic bovine bone and bioactive glass associated with platelet rich plasma. Braz. Dent. J., 22(1):14-20, 2011.

Batista, M. A.; Leivas, T. P.; Rodrigues, C. J.; Arenas, G. C. F.; Belitardo, D. R. \& Guarniero, R. Comparison between the effects of platelet-rich plasma and bone marrow concentrate on defect consolidation in the rabbit tibia. Clinics (São Paulo), 66(10):1787-92, 2011.
Bi, L.; Cheng, W.; Fan, H. \& Pei, G. Reconstruction of goat tibial defects using an injectable tricalcium phosphate/chitosan in combination with autologous platelet-rich plasma. Biomaterials, 31(12):3201-11, 2010.

Bourque, W. T.; Gross, M. \& Hall, B. K. A histological processing technique that preserves the integrity of calcified tissues (bone, enamel), yolky amphibian embryos, and growth factor antigens in skeletal tissue. $J$. Histochem. Cytochem., 41(9):1429-34, 1993.

Cardiff, R. D.; Miller, C. H. \& Munn, R. J. Manual hematoxylin and eosin staining of mouse tissue sections. Cold Spring Harb Protoc., 2014(6):6558, 2014.

Demir, B.; Sengün, D. \& Berberog `lu, A. Clinical evaluation of platelet-rich plasma and bioactive glass in the treatment of intra-bony defects. J. Clin. Periodontol., 8(34):709-15, 2007.

Fernandes, H. R.; Gaddam, A.; Rebelo, A.; Brazete, D.; Stan, G. E. \& Ferreira, J. M. F. Bioactive glasses and glass-ceramics for healthcare applications in bone regeneration and tissue engineering. Materials (Basel), 11(12):2530, 2018.

Fiume, E.; Barberi, J.; Verné, E. \& Baino, F. Bioactive glasses: from parent 45S5 composition to scaffold-assisted tissue-healing therapies. J. Func. Biomater, 9(1):24, 2018.

Gomes, D. S.; Santos, A. M. C.; Neves, G. A. \& Menezes, R. R. A brief review on hydroxyapatite production and use in biomedicine. Cerâmica, 65(374):282-302, 2019.

Kasten, P.; Vogel, J.; Geiger, F.; Niemeyer, P.; Luginbühl, R. \& Szalay, K. The effect of platelet-rich plasma on healing in critical-size long-bone defects. Biomaterials, 29(29):3983-92, 2008.

Meschi, N.; Castro, A. B.; Vandamme, K.; Quirynen, M. \& Lambrechts, P. The impact of autologous platelet concentrates on endodontic healing: a systematic review. Platelets, 27(7):613-33, 2016.

Oryan, A.; Meimandi Parizi, A.; Shafiei-Sarvestani, Z. \& Bigham, A.S. Effects of combined hydroxyapatite and human platelet rich plasma on bone healing in rabbit model: radiological, macroscopical, hidtopathological and biomechanical evaluation. Cell Tissue Bank, 13(4):639-51, 2012.

Polo-Corrales, L.; Latorre-Esteves, M. \& Ramirez-Vick, J. E. Scaffold design for bone regeneration. J. Nanosci. Nanotechnol., 14(1):15-56, 2014.

Rodriguez, I. A.; Growney Kalaf, E. A.; Bowlin, G. L. \& Sell, S. A. Plateletrich plasma in bone regeneration: engineering the delivery for improved clinical efficacy. Biomed Res. Int., 2014:392398, 2014.

Rolvien, T.; Hahn, M.; Siebert, U.; Püschel, K.; Wilke, H. J.; Busse, B.; Amling, M. \& Oheim, R. Vertebral bone microarchitecture and osteocyte characteristics of three toothed whale species with varying diving behaviour. Sci. Rep., 7(1):1604, 2017.

Scimeca, M.; Salustri, A.; Bonanno, E.; Nardozi, D.; Rao, C.; Piccirilli, E.; Feola, M.; Tancredi, V.; Rinaldi, A.; Iolascon, G.; et al. Impairment of PTX3 expression in osteoblasts: a key element for osteoporosis. Cell Death Dis., 8(10):e3125, 2017.

Yilmaz, D.; Dogan, N.; Ozkan, A.; Sencimen, M.; Ora, B. E. \& Mutlu, I. Effect of platelet rich fibrin and beta tricalcium phosphate on bone healing. Ahistological study in pigs. Acta Cir. Bras., 29(1):59-65, 2014.

Yu, T.; Pan, H.; Hu, Y.; Tao, H.; Wang, K. \& Zhang, C. Autologous plateletrich plasma induces bone formation of tissue-engineered bone with bone marrow mesenchymal stem cells on beta-tricalcium phosphate ceramics. J. Orthop. Surg. Res., 12(1):178, 2017.

Zhang, Y. D.; Wang, G.; Sun, Y. \& Zhang, C. Q. Combination of platelet-rich plasma with degradable bioactive borate glass for segmental bone defect repair. Acta Orthop. Belg., 77(1):110-5, 2011.

\section{Corresponding author:}

Volodymyr S. Chornyi, MD, PhD

Department of Traumatology \& Orthopedics

Bogomolets National Medical University

13, T.Shevchenka Blvd

01601, Kyiv

UKRAINE

Received: 06-10-2020

Accepted: $22-10-2020$

Email: oncoortoped@gmail.com 